\title{
One-pot Diels-Alder cycloaddition/gold(I)-catalyzed 6-endo-dig cyclization for the synthesis of the complex bicyclo[3.3.1]alkenone framework
}

\author{
Boubacar Sow, Gabriel Bellavance, Francis Barabé and Louis Barriault ${ }^{\star} \S$
}

\section{Full Research Paper}

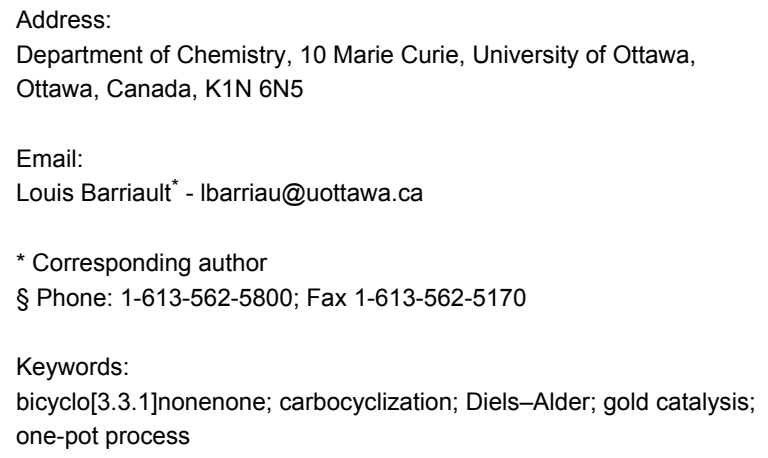

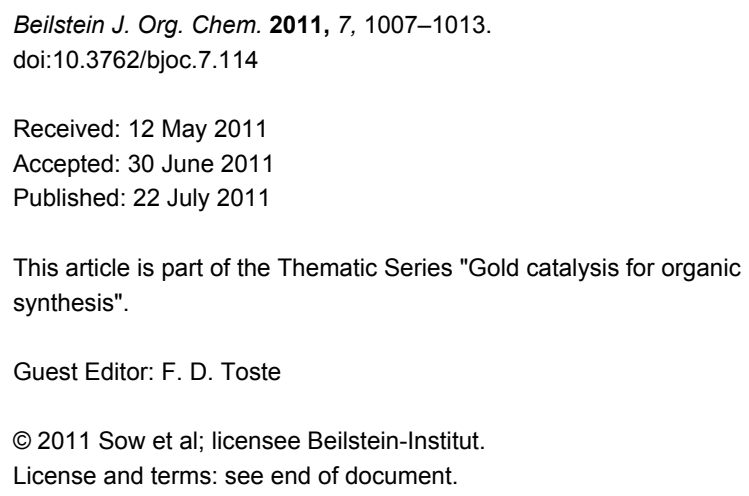

\begin{abstract}
The rapid synthesis of bicyclo[m.n.1]alkanone cores possessing quaternary carbon centers adjacent to a bridged ketone represents a significant synthetic challenge. This type of architectural feature is embedded in various complex biologically active compounds such as hyperforin and garsubellin A. Herein, we report a highly diastereoselective one-pot Diels-Alder reaction/Au(I)-catalyzed carbocyclization to generate bicyclo[3.3.1] alkanones in yields ranging from $48-93 \%$.
\end{abstract}

\section{Introduction}

Highly oxygenated and densely substituted carbon-bridged medium sized rings such as $\mathbf{1}$ are commonly found in nature as structural frameworks of many important bioactive natural products, and in particular, polycyclic polyprenylated acetylphloroglucinols (PPAPs) (Figure 1) [1]. In the past decades, more than 100 PPAPs exhibiting a wide variety of biological activities (antibiotic, anti-HIV, anti-oxidant, etc.) have been isolated from Guttiferrea plants such as hyperforin (2) [2-6] and garsubellin A (3) [7,8]. The challenging synthesis of PPAP structures combined with their promising therapeutic potential has drawn attention from several research groups [9-12].

In 2009, we reported a mild and highly efficient method to generate carbon-bridged frameworks of various sizes through a gold(I)-catalyzed carbocyclization [13]. Although the cyclization of enol ether 5 can produce 5-exo and 6-endo products, we found that gold complexes $\mathbf{6}$, having bulky phosphine ligands such as 2-bis(tert-butylphosphino)biphenyl, gave exclusively the 6-endo-dig cyclized products 7 (Scheme 1). In the course of 
<smiles>CC(C)=CCCC12CCC(CC=C(C)C)(C(=O)C(CC=C(C)C)=C1O)C(=O)C(CC=C(C)C)(C(C)C)C2=O</smiles>

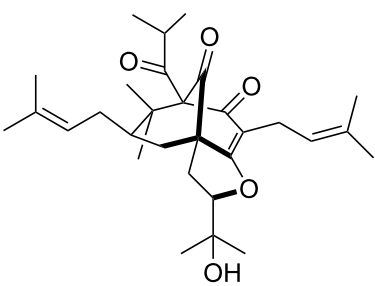

hyperforin (2)

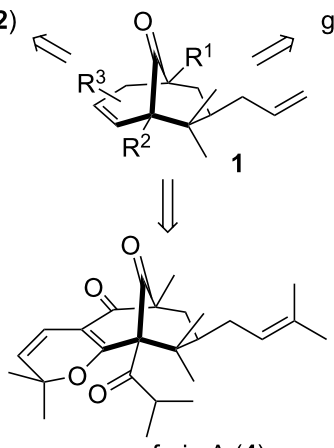

papuaforin $\mathrm{A}(\mathbf{4})$

Figure 1: Structures of naturally occurring PPAPs.

our studies directed towards the synthesis of naturally occurring PPAPs and related carbon-bridged ketone scaffolds, we envisioned that PPAP framework $\mathbf{1}$ could be generated via a $\mathrm{Au}(\mathrm{I})$-catalyzed cyclization [14-22].

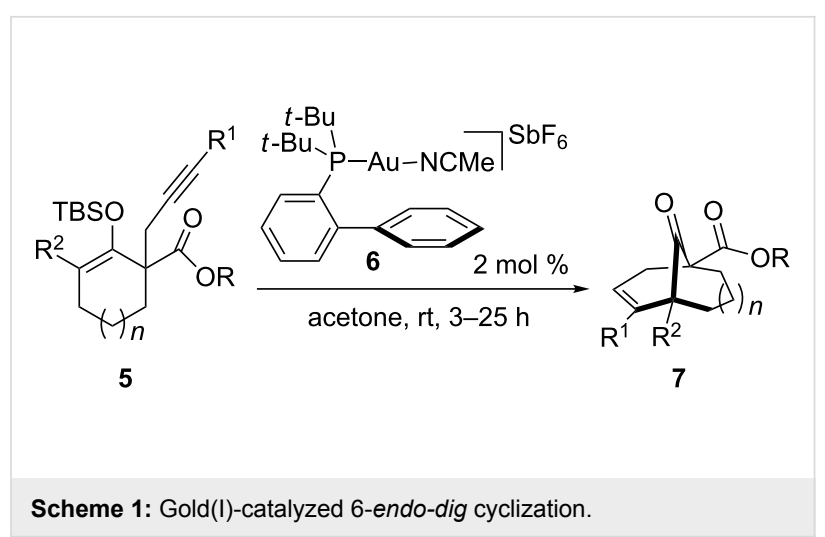

\section{Results and Discussion}

The synthesis began by a $C$-alkylation of enone 8 [23] using LDA and MeI to give the corresponding ketone in $90 \%$ yield (Scheme 2). A second alkylation to add the propargyl chain was carried out using LDA and propargyl bromide to afford 9 in $62 \%$ yield as an inseparable mixture of diastereomers $(\mathrm{dr}=3: 1)$. Subsequently, conjugate addition of methylmagnesium bromide in the presence of a catalytic amount of $\mathrm{CuI}$ provided the corresponding ketone in 53\% yield. The ketone was then treated with TBSCl, NaI and triethylamine to give the desired silylenol ether 10 in $46 \%$ yield, which upon exposure to the $\mathrm{Au}(\mathrm{I})$ complex $6(2 \mathrm{~mol} \%)$ provided the desired bicyclo[3.3.1]nonenone $\mathbf{1 1}$ in $88 \%$ yield. It is important to note<smiles>C=CCC1CCC(=O)C=C1C</smiles>

1) LDA, THF, $-78^{\circ} \mathrm{C}$ Mel, $90 \%$

2) LDA, THF, $-78^{\circ} \mathrm{C}$<smiles>C#CC[18OH]</smiles><smiles>C#CC[C@]1(C)CC(CC=C)C(C)=CC1=O</smiles>

1) $\mathrm{MeMgBr}$, Cul (10 mol \%) THF-DMS

$0{ }^{\circ} \mathrm{C}, 53 \%$

2) $\mathrm{TBSCl}, \mathrm{Nal}, \mathrm{MeCN}$ $46 \%$<smiles>C#CC[C@]1(C)CC(CC=C)C(C)(C)C=C1O[Sb]</smiles>

10

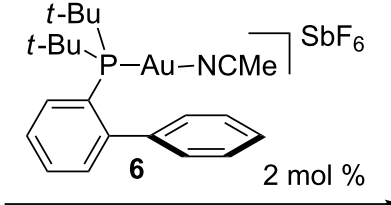

DCM, rt, 12 h $88 \%$

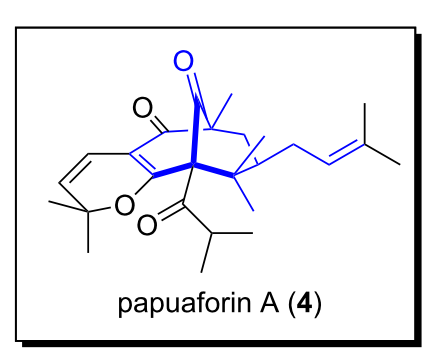

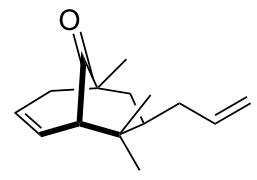

11 


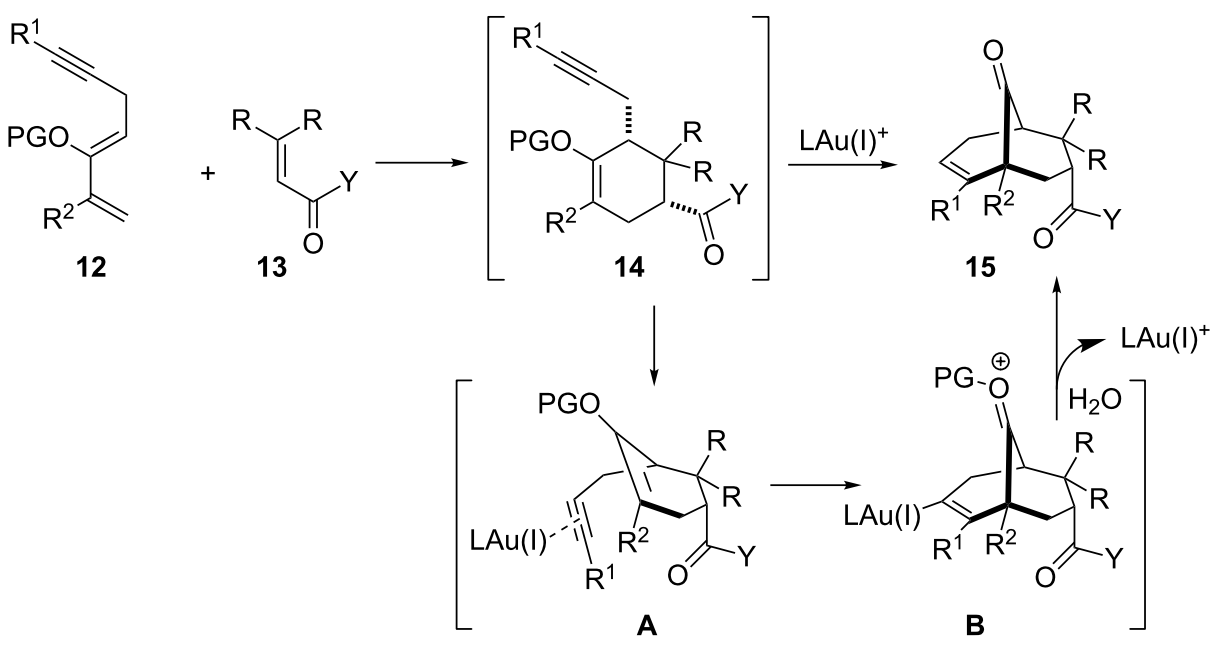

Scheme 3: Proposed domino Diels-Alder reaction/gold(I)-catalyzed cyclization.

that the $\mathrm{Au}(\mathrm{I})$-catalyzed cyclization proceeds in high yields in a sterically congested environment. The synthesis of the core of papuaforin (11) was achieved in five steps from enone $\mathbf{8}$.

However, one might recognize that the low chemical yields encountered in some steps undermine the efficacy of the $\mathrm{Au}(\mathrm{I})$ catalyzed cyclization approach. In order to solve this issue, we assumed that bicyclo[3.3.1]nonenone scaffolds can be directly obtained through an intermolecular Diels-Alder reaction $/ \mathrm{Au}(\mathrm{I})$ catalyzed 6-endo-dig carbocyclization (Scheme 3). Cycloaddition between diene $\mathbf{1 2}$ and dienophile $\mathbf{1 3}$ should provide the endo cycloadduct $\mathbf{1 4}$, which, in the presence of a gold(I) catalyst, would form the gold complex A. This undergoes a carbocyclization of enol ether [24-31] to afford intermediate $\mathbf{B}$, which after proto-deauration and hydrolysis affords the bridgehead ketone 15. The attractive feature of this process resides in the ability to generate four new stereogenic centers and three new $\mathrm{C}-\mathrm{C}$ bonds in one single operation.

To validate the above hypothesis, diene 16 ( $Z$-isomer) was heated with $\mathrm{N}$-phenylmaleimide in toluene at $150{ }^{\circ} \mathrm{C}$, for two hours, by microwave irradiation (Scheme 4) (see Supporting Information File 1 for experimental procedures). The solution containing the Diels-Alder adduct $\mathbf{1 7}$ was cooled down to room temperature and $2 \mathrm{~mol} \%$ of $\mathrm{Au}(\mathrm{I})$ complex 6 was added. The bridgedhead ketone $\mathbf{1 8}$ was obtained in $80 \%$ yield as a single diastereomer. The relative stereochemistry of $\mathbf{1 8}$ was unambiguously established by X-ray analysis (see Supporting Information File 2). With this result in hand, we explored the scope of this sequential reaction (Table 1).<smiles>C#CC/C=C(\S[OH2+])C(=C)CC=C</smiles><smiles>C#CC[C@H]1C(CC)=C(CC=C)C[C@H]2C(=O)N(c3ccccc3)C(=O)[C@@H]21</smiles><smiles>CC(C)[SbH2]C(C)(C)C</smiles>

6 
1

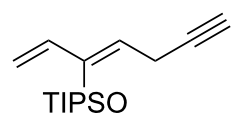

19

2

19

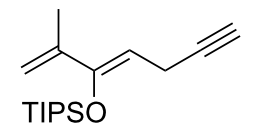

20

4

20

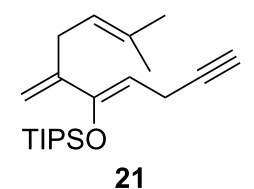<smiles>O=C1C=CC(=O)[PH2]1</smiles><smiles>O=C1C=CC(=O)O1</smiles><smiles>O=C1C=CC(=O)[PH2]1</smiles><smiles>O=C1C=CC(=O)O1</smiles><smiles>O=C1C=CC(=O)[PH2]1</smiles>

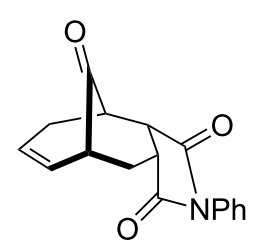

24

(93\%)

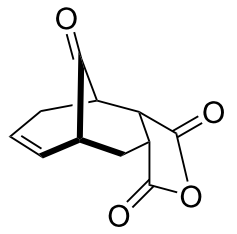

25

(51\%)

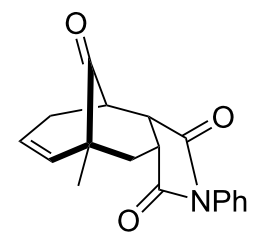

26

(88\%)

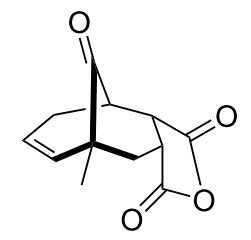

27

(50\%)

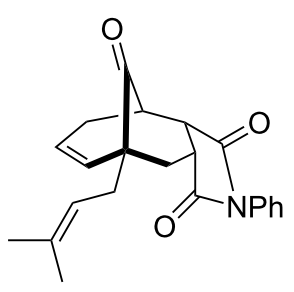

28

(81\%) 
Table 1: Results of the one-pot Diels-Alder reaction/Au(I)-catalyzed cyclization. (continued)

7

8

9
21<smiles>C#CC/C=C(\OC(=O)[I-])C(=C)c1ccccc1</smiles>

22<smiles>O=C1C=CC(=O)O1</smiles><smiles>O=C1C=CC(=O)[PH2]1</smiles><smiles>O=C1C=CC(=O)O1</smiles><smiles>O=C1C=CC(=O)O1</smiles><smiles>CC(C)=CCC12CC=CC(C1)C(=O)CC(=O)OC2=O</smiles>

29

$(78 \%)$

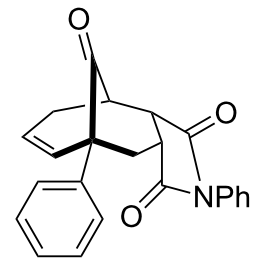

30

(77\%)

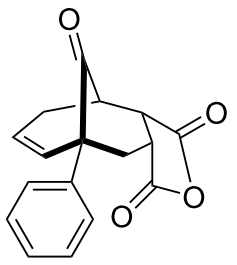

31

(48\%)

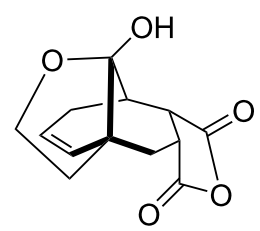

32

23

alsolated yield and $\mathrm{dr}>25: 1$ in all cases.

One-pot cycloaddition/cyclization of dienes 19 and $20(Z / E=$ 6:1 ca.) with $N$-phenylmaleimide gave ketones $\mathbf{2 4}$ and $\mathbf{2 6}$ in 93 and $88 \%$ yield, respectively, as the sole diastereomers (Table 1 , entries 1 and 3). The use of maleic anhydride as the dienophile also provided the desired products $\mathbf{2 5}$ and $\mathbf{2 7}$, albeit in lower yields of 51 and $50 \%$, respectively (Table 1, entries 2 and 4). Prenylated diene $\mathbf{2 1}$ was smoothly converted to ketones $\mathbf{2 8}$ and 29 in 81 and 78\% yield, respectively (Table 1, entries 5 and 6). Table 1, entries 7 and 8 reveal that the diene 22, bearing a phe- nyl group at $\mathrm{C} 2$, can be stereoselectively transformed into the desired bridgehead ketones $\mathbf{3 0}$ and $\mathbf{3 1}$ in 77 and 48\% yields, respectively. Interestingly, hemiketal $\mathbf{3 2}$ was isolated in 56\% yield, which suggests that the MOM group was cleaved during the $\mathrm{Au}(\mathrm{I})$-catalyzed carbocyclization. It is important to note that the E-isomer of dienes 19-23 (minor compound) do not react with the dienophiles, but rather isomerized to the $Z$-form under the reaction conditions, thus, ensuring the formation of a single diastereomer. 
Table 2: One-pot Diels-Alder cycloaddition/Au(I)-catalyzed carbocyclization of internal alkynes.<smiles>[R]C#CCC=C(O[Te])C(=C)CC=C</smiles>

$33-36$

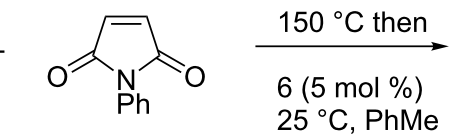

$25^{\circ} \mathrm{C}, \mathrm{PhMe}$

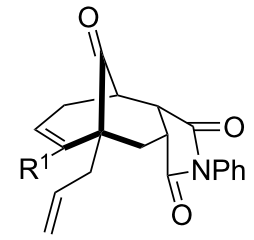

37-40

\begin{tabular}{lll}
\hline entry & substituent $\mathrm{R}^{1}$ & product \\
\hline
\end{tabular}

1<smiles>Cc1ccccc1</smiles>

33<smiles>Cc1ccc(C)cc1</smiles>

34

3<smiles>COc1ccc(C)cc1</smiles>

35<smiles>C=C(C)c1ccccc1</smiles>

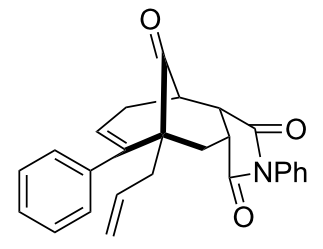

37

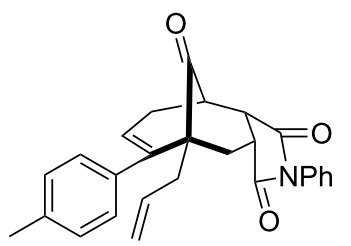

38<smiles>C=CCC12CCC(CC(=O)C1Cc1ccccc1)C1C(=O)NC(=O)C1C2</smiles>

39

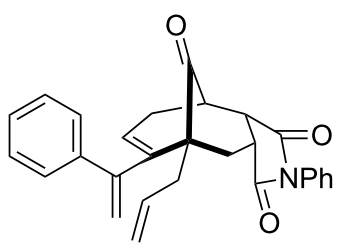

68

40

alsolated yield and dr >25:1 in all cases.

To extend the scope of the reaction, other dienes possessing internal alkynes were also investigated (Table 2). It can be seen that large substituents at the alkyne terminal position did not affect the efficacy of the reaction. Intermolecular cycloaddition/ $\mathrm{Au}(\mathrm{I})$-catalyzed cyclization of aryl acetylene dienes 33-35 provided the desired ketones $\mathbf{3 7 - 3 9}$ in yields ranging from 68 to 91\% (Table 2, entries 1-3). Remarkably, enyne 36 was converted to $\mathbf{4 0}$ in $79 \%$ yield (Table 2 , entry 4 ).

\section{Conclusion}

In summary, we have developed an efficient stereoselective method for the construction of bicyclic[3.3.1]nonenone frameworks. This one-pot Diels-Alder/Au(I)-catalyzed carbocyclization process provides access to synthetically useful motifs that are found in numerous naturally occurring PPAPs. In addition, the $\mathrm{Au}(\mathrm{I})$-catalyzed cyclization proved to be tolerant of a sterically crowded environment. Further studies to develop an 
enantioselective version of this reaction and its application to the total synthesis of hyperforin (2) and garsubellin A (3) are underway and will be reported in due course.

\section{Supporting Information}

\section{Supporting Information File 1}

Experimental procedures, characterization data, ${ }^{1} \mathrm{H}$ NMR and ${ }^{13} \mathrm{C}$ NMR spectra.

[http://www.beilstein-journals.org/bjoc/content/ supplementary/1860-5397-7-114-S1.pdf]

\section{Supporting Information File 2}

$\mathrm{X}$-ray data of compound $\mathbf{1 8}$.

[http://www.beilstein-journals.org/bjoc/content/

supplementary/1860-5397-7-114-S2.cif]

\section{Acknowledgements}

We thank the Natural Science and Engineering Research Council of Canada (NSERC), Merck Research Laboratories, Merck Frosst Canada, Boehringer Ingelheim (Laval), PREA, Canada Foundation for Innovation, Ontario Innovation Trust and the University of Ottawa for generous funding. F.B. thanks NSERC for post-graduate scholarship (CGS-D1).

\section{References}

1. Ciochina, R.; Grossman, R. B. Chem. Rev. 2006, 106, 3963. doi:10.1021/cr0500582

2. Bystrov, N. S.; Chernov, B. K.; Dobrynin, V. N.; Kolosov, M. N. Tetrahedron Lett. 1975, 16, 2791. doi:10.1016/S0040-4039(00)75241-5

3. Müller, W. E.; Singer, A.; Wonnemann, M.; Hafner, U.; Rolli, M.; Schäfer, C. Pharmacopsychiatry 1998, 31, 16. doi:10.1055/s-2007-979341

4. Verotta, L.; Appendino, G.; Bombardelli, E.; Brun, R. Bioorg. Med. Chem. Lett. 2007, 17, 1544. doi:10.1016/j.bmcl.2006.12.100

5. Gey, C.; Kyrylenko, S.; Henning, L.; Nguyen, L.-H. D.; Büttner, A.; Pham, H. D.; Giannis, A. Angew. Chem., Int. Ed. 2007, 46, 5219. doi:10.1002/anie.200605207

6. Moore, L. B.; Goodwin, B.; Jones, S. A.; Wisely, G. B.; Serabjit-Singh, C. J.; Willson, T. M.; Collins, J. L.; Kliewer, S. A. Proc. Natl. Acad. Sci. U. S. A. 2000, 97, 7500. doi:10.1073/pnas.130155097

7. Fukuyama, Y.; Kuwayama, A.; Minami, H. Chem. Pharm. Bull. 1997, 45, 947.

8. Fukuyama, Y.; Minami, H.; Kuwayama, A. Phytochemistry 1998, 49, 853. doi:10.1016/S0031-9422(98)00126-5

9. Shimizu, Y.; Shi, S. L.; Usuda, H.; Kanai, M.; Shibasaki, M. Angew. Chem., Int. Ed. 2010, 49, 1103. doi:10.1002/anie.200906678

10. Kuramochi, A.; Usuda, H.; Yamatsugu, K.; Kanai, M.; Shibasaki, M. J. Am. Chem. Soc. 2005, 127, 14200. doi:10.1021/ja055301t

11. Danishefsky, S. J.; Siegel, D. R. J. Am. Chem. Soc. 2006, 128, 1048. doi:10.1021/ja057418n
12. Ahmad, N. M.; Rodeschini, V.; Simpkins, N. S.; Ward, S. E.; Blake, A. J. J. Org. Chem. 2007, 72, 4803. doi:10.1021/jo070388h

13. Barriault, L.; Barabé, F.; Bétournay, G.; Bellavance, G. Org. Lett. 2009, 11, 4236. doi:10.1021/ol901722q

14. Toste, F. D.; Gorin, D. J. Nature 2007, 446, 395. doi:10.1038/nature05592

15. Jiménez-Núñez, E.; Echavarren, A. M. Chem. Commun. 2007, 333. doi:10.1039/B612008C

16. Fürstner, A.; Davies, P. W. Angew. Chem., Int. Ed. 2007, 46, 3410. doi:10.1002/anie.200604335

17. Hashmi, A. S. K. Chem. Rev. 2007, 107, 3180. doi:10.1021/cr000436x

18. Gorin, D. J.; Sherry, B. D.; Toste, F. D. Chem. Rev. 2008, 108, 3351. doi:10.1021/cr068430g

19. Li, Z.; Brouwer, C.; He, C. Chem. Rev. 2008, 108, 3239. doi:10.1021/cr068434I

20. Arcadi, A. Chem. Rev. 2008, 108, 3266. doi:10.1021/cr068435d

21. Skouta, R.; Li, C.-J. Tetrahedron 2008, 64, 4917. doi:10.1016/j.tet.2008.03.083

22. Shapiro, N. D.; Toste, F. D. Synlett 2010, 5, 675. doi:10.1055/s-0029-1219369

23. Johnson, W. S.; McCarry, B. E.; Markezich, R. L.; Boots, S. G. J. Am. Chem. Soc. 1980, 102, 352. doi:10.1021/ja00521a057

24. Dankwardt, J. W. Tetrahedron Lett. 2001, 42, 5809. doi:10.1016/S0040-4039(01)01146-7

25. Suhre, M. H.; Reif, M.; Kirsch, S. F. Org. Lett. 2005, 7, 3925. doi:10.1021/ol0514101

26. Staben, S. T.; Kennedy-Smith, J. J.; Huang, D.; Corkey, B. K.; LaLonde, R. L.; Toste, F. D. Angew. Chem., Int. Ed. 2006, 45, 5991. doi:10.1002/anie.200602035

27. Linghu, X.; Kennedy-Smith, J. J.; Toste, F. D. Angew. Chem., Int. Ed. 2007, 46, 7671. doi:10.1002/anie.200702695

28. Lee, K.; Lee, P. H. Adv. Synth. Catal. 2007, 349, 2092. doi:10.1002/adsc. 200700304

29. Minnihan, E. C.; Colletti, S. L.; Toste, F. D.; Shen, H. C. J. Org. Chem. 2007, 72, 6287. doi:10.1021/jo071014r

30. Kusama, H.; Karibe, Y.; Onizawa, Y.; Iwasawa, N. Angew. Chem., Int. Ed. 2010, 49, 4269. doi:10.1002/anie.201001061

31. Ito, H.; Ohmiya, H.; Sawamura, M. Org. Lett. 2010, 12, 4380. doi:10.1021/ol101860j

\section{License and Terms}

This is an Open Access article under the terms of the Creative Commons Attribution License (http://creativecommons.org/licenses/by/2.0), which permits unrestricted use, distribution, and reproduction in any medium, provided the original work is properly cited.

The license is subject to the Beilstein Journal of Organic Chemistry terms and conditions: (http://www.beilstein-journals.org/bjoc)

The definitive version of this article is the electronic one which can be found at: doi:10.3762/bjoc.7.114 